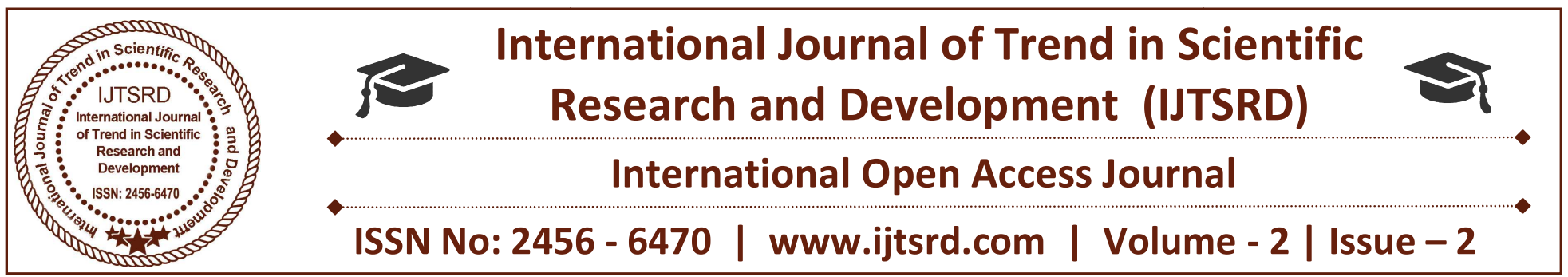

\title{
Antimicrobial activity of mustard against Mackerel fish pathogens
}

\author{
Khushali Chandulal Ahire \\ Department of microbiology, R. K. Talreja College \\ of Arts, Science and Commerce, Ulhasnagar, \\ Thane, Maharashtra, India
}

\author{
Ranjana Ganesh Khade \\ Department of microbiology, R. K. Talreja College \\ of Arts, Science and Commerce, Ulhasnagar, \\ Thane, Maharashtra, India
}

\section{ABSTRACT}

Fish is a nutritionally rich food which is more prone to spoilage. It harbours variety of pathogens. Mustard is medicinally important spice. Isolation of Mackerel fish pathogens was done using selective and differential media. Nutritional characterization of mustard was carried out with respect to carbohydrate, protein and fat content. Antimicrobial activity of mustard against fish pathogen was studied using mustard paste and various mustard extracts. The optimum concentration of the extracts to be used for fish preservation was determined by agar cup diffusion method. Mustard crude oil extract prepared using chloroform and methanol mixture showed prominent antimicrobial activity. Marination effect of mustard paste, mustard crude oil extract and mustard oil revealed the preservative effect of mustard. Thus, the present study promotes the use of mustard as a natural preservative agent for seafood industry.

Keywords: Mackerel fish, Mustard, Antimicrobial activity, Preservative

\section{INTRODUCTION}

Fish and varied products made from them constitute a wide range of nutritional food. Fish are more prone to spoilage due to their nutrient level. Loss of freshness of fish is followed by spoilage which is a complete combination of biological, physical and chemical processes. (Petronillah R. Sichewo et. al., 2013). Mackerel (Rastrelliger kanagurta) fish is the most common edible fish. It is economically cheap and abundantly available fish in India. Mackerel Fish is an excellent and relatively a cheaper protein source of high biological value. Many microorganisms enter seafood processing chain because of inadequate process control, poor standards of hygiene and sanitation in processing plants and post-production contamination during incorrect handling or storage (Eze, E. I., Echezona et al., 2010). The pathogenic bacteria, Salmonella typhi, Pseudomonas aeruginosa, Escherichia coli, Staphylococcus aureus and Enterococcus faecalis have been reported to be associated with fish (Anita Dua et al., 2014).

Fishes have been stored at freezing temperature for its preservation. Freezing kills some bacteria, but the ones not killed will grow upon thawing. Some bacteria that grow on fish, like Pseudomonas species, Moraxella species, Alcaligenes species, Flavobacterium species, etc can survive freezing temperature and will resume growth when thawed (Frazier and Westhoff et al., 1988). The use of natural preservatives to increase the shelf-life of meat products has been as promising as they possess antioxidant and antimicrobial properties (Amir Reza Shaviklo et al., 2015).

Natural extracts and essential oils have long been utilized to extend shelf life and the sensory quality of foods (Ana Clarissa dos Santos Pires et al., 2009). Medicinal plants are of great significance on the health of individuals and communities. The seeds of 
Brassica nigra have been used as a spice and medicine since ancient times (Ana Clarissa dos Santos Pires et al., 2015). B. nigra has been reported as an effective medicinal seed with antimicrobial property (Amanuel Amare et al., 2015). The present investigation is an attempt to reveal the preservative potential of the mustard towards Mackerel fish.

\section{MATERIALS AND METHODS}

\section{Collection of fish}

Mackerel (Rastrelliger kanagurta) fish were collected from fish market and local vendors of Kalyan and Ulhasnagar, dist. Thane, Maharashtra, India. 32 mackerel fish having weight and total length in the range 85-100 gms and 19-22 $\mathrm{cm}$ respectively were selected for study.

\section{Microbiological analysis and Characterization of} fish pathogen

Suspension was made by taking a piece of fish $(1 \times 1 \mathrm{~cm})$ in sterile saline. The suspension was diluted and plated out on Nutrient agar plate. A Loopful, suspension was streak inoculated on Sterile MacConkey's agar, Salmonella shigella agar, TCBS agar plate. Plates were incubated at $37^{\circ} \mathrm{C}$ for $24 \mathrm{hrs}$. Fish isolates were characterized on the basis of microscopic, cultural and biochemical test.

\section{Collection of mustard seeds and Nutritional} characterization of mustard seeds

Black mustard (Brassica nigra) unpolished seed were collected from market of Kalyan. The mustard seeds were washed and dried in oven and converted into powdered from for nutritional characterization study.

Protein content was determined by using Folin phenol reagent (Lowry et al., 1951) and total Carbohydrate by Phenol Sulphuric acid method (dubois et al., 1956). Total fat content was done by extraction of lipids (Bligh and Dyer et.al., 1959) and the mineral content was studied by Ash method.

\section{Antimicrobial study of Mustard against fish pathogens}

Antimicrobial activity of mustard was studied against fish isolates using mustard paste and mustard extracts. Aqueous and solvent extracts of mustard were prepared as per Amanuel Amare et al., (2012). Solvent used were ethanol, chloroform, methanol, acetone and chloroform methanol mixture (2:1). After complete evaporation of the solvent, $1 \mathrm{gm}$ of extracted matter was dissolved in sterile distilled water and tested for its antimicrobial activity against fish isolate by agar cup diffusion method. Fish isolate suspension was added to sterile molten nutrient agar and poured into sterile empty plate. Wells were made in solidified agar plate and different extract $(10 \%)$ were added into it. Plates were incubated at $37^{\circ} \mathrm{C}$ for $24 \mathrm{hrs}$. Zone of inhibition was observed and measured. The optimum concentration of extracts for fish preservation was also determined by using varying concentrations $(0.01$ $-10 \%)$ of mustard extracts.

\section{RESULTS AND DISCUSSION}

Nature has wide source of medical agents and many drugs are isolated from nature. Brassica nigra is a member of the Brassicaceae family. Seeds have a pungent taste and rich nutty odour. It is a weedy plant cultivated for its seeds as a spice and leaves used as vegetable (Alyaa Sabti Jasim et al., 2012). The mustard seeds of globular black color and about $1 \mathrm{~mm}$ in diameter were procured and studied for its nutritional content. Table 1 shows the nutritional content of collected mustard seeds.

Mackerel (Rastrelliger kanagurta) fish were collected from fish market and local vendors of Kalyan and Ulhasnagar. Physiological analysis was done on the basis of weight, color, texture, softness and smell. Microbiological analysis of fish collected from Ulhasnagar showed not only very high count of bacteria but also showed presence of enteric pathogenic bacteria. The average bacterial count by standard plate count method on the surface of fish was found to be in the range of $4.6 \times 10^{7}-7.2 \times 10^{8}$ $\mathrm{cfu} / \mathrm{mm}^{2}$. All the collected fish showed presence of $E$ coli on their surface. This indicates contamination of fish with polluted water and also leads to prediction of presence of other Entero pathogens. Hence, all the collected fish were also tested for presence of Salmonella, Shigella and Vibrio spp. Out of 32 fish, 21 showed presence of Salmonella spp while 5 showed presence of Vibrio spp. None of the fish showed presence of shigella spp. Anita Dua et al., (2014) has isolated many pathogenic bacteria from fish surface.

Antimicrobial role of mustard was studied against $E$. coli culture as it was found to be associated with all the fish. Mustard was used in different form as aqueous extract, solvent extracts and oil extracted from mustard. Crude oil of mustard was prepared by combination of chloroform and methanol solvent. All 
the traces of solvents were removed by evaporation. The agar diffusion assay is most commonly used method for quantifying the ability of extracts to inhibit bacterial growth. The extract diffuses freely in the solid nutrient medium. All the prepared extracts except aqueous showed antimicrobial activity against isolated $E$ coli. Maximum antimicrobial activity was observed with crude oil extract followed by ethanol extract (Fig. 1). Acetone and chloroform gave comparatively same activity and least activity was observed with methanol extract. The optimum concentration of the extracts to be used for fish preservation was determined by taking varying concentrations $(0.01-10 \%)$ of different solvent extracts of mustard. The antimicrobial activity shown by varying concentrations of the extracts against $E$. coli isolated from fish is shown in Fig. 2. Least activity was observed with methanol and chloroform extracts while crude extract obtained using methanol and chloroform mixture showed highest antimicrobial activity. The crude extract was active against $E$. coli even at $0.01 \%$ concentration and the activity increased with increase in concentration. All other extract did not show any activity at 0.01 and $0.1 \%$ concentration. Shakeel Ahmad Khan et al., (2016) has studied antimicrobial activity of brown mustard extract and reported maximum antimicrobial activity from methanol extract and $n$-hexane fraction of methanol extract against bacteria while highest antifungal activity was observed with acetone and $n$-hexane fraction of methanol extract.

\section{CONCLUSION}

The use of natural preservative to increase shelf life of seafood has been promising due to their antioxidants and antimicrobial properties (Amir Reza Shaviklo et al., 2015). The present study proves helpful in determining the efficacy of mustard and its extracts as natural preservatives to enhance the shelf life of fish.

\section{BIBILOGRAPHY}

1. Alya Sabti jasim (2012), Antibacterial activity of oils extracts of Brassica nigra seeds on some bacteria isolated from plaque and healthy teeth in children (1-5) years, Basrah Journal of Scienec.3(1):105-119.

2. Amir Raza Shaviklo (2012), Development of fish protein powder as an ingredient for food applications: a review, Food Sci Technol, 52(2): 648-661.
3. Amanuel Amar, Atsede Hadush, Haftu Aregawi and Nigisti Kide (2012), Antibacterial activity of oil extracts of Black Mustard (Brassica nigra) seeds against bacteria isolated from fresh juice in selected areas of Axum town, a peer revoew E-3 journal of science innovation technology. 4(4): $2278-1145$.

4. Anita dua, Subhash Chander, Sharad Agrawal and Ritu Mahajan (2015), Antioxidants from defatted Indian Mustard (Brassica Juncea)protect biomolecules against in vitro oxidation, Physiol Mol Biol Plants , 20(4): 539-543.

5. Ana Clarissa dos Santos Pires, Nilda de Fatima Ferreira Soares, Nélio Jose de Andrade, Luis Henrique Mendes da Silva, Geany Peruch Camilloto, Patricia Campos Bernardes (2009). Increased preservation of sliced mozzarella cheese by antimicrobial sachet incorporated with allyl isothiocynate, Brazilian Journal of Microbiology, 4(10): 1002-1008.

6. Bligh, E.C. and Dyer WJ (1959), A rapid method for total lipid extraction and purification. Canadian al Journal of Biochemistry and Physiology, 37(8): 911-917.

7. DuBois, M., Gilles, K.A., Hamilton, J.K., Rebers, P.A. and Smith, F. (1956) Colorimetric method for determination of sugars and related substances. Anlytical Chemistry, 28: 350-356.

8. Eze. E.I.Echezona, B. C. and Uzodinma, E. C. (2010), Isolation and identification of pathogenic bacteria associated with frozen mackerel fish (Scomber scombrus) in a humid tropical environment, African Journal of Agricultural Research, 6(8): 1947-1951.

9. FAO report, 2016.

10. Lowry, O. H.; Rosebrough, N. J.; Farr, A. L.; Randall, R. J. (1951). "Protein measurement with the Folin phenol reagent". Journal of Biological Chemistry. 193 (1): 265-75.

11. Mazia, D., Brewer, P.A., Alfert, M., (1953). The cytochemical staining and measurement of protein with mercuric bromophenol blue. Biol. Bull. 104.

12. Petronillah R Sichewo, Robert K. Gono, John V. Muzvondiwa, Nyoni Sizanobuhle (2013), Isolation and Identification of Pathogenic Bacteria in Edible Fish: A Case Study of Fletcher Dam in Gweru, Zimbabwe, International Journal of Science and Research (IJSR), 2(9): 2319-7064. 
International Journal of Trend in Scientific Research and Development (IJTSRD) ISSN: 2456-6470

13. Sandra G Gomes de saravia, Christine C. Gaylarde (2015), The antimicrobial activity of an aqueous extract of Brassica nigra.

Antibacterial, Antifungal and GC-MS Analysis of seeds of Mustard Brown International Journal of Pharmaceutical Chemistry, 06 (04).

14. Shakel Ahemad Khan, Sammia Shahid, Mehwish Jameel and Aqeel Ahmad (2016), In vitro

Table 1: Nutritional analysis of mustard seeds

\begin{tabular}{|l|l|}
\hline Nutritional factor & Content/gm \\
\hline Protein content & $142 \pm 2.50 \mathrm{mg} / \mathrm{gm}$ \\
\hline Total carbohydrate & $112 \pm 1.75 \mathrm{mg} / \mathrm{gm}$ \\
\hline Total mineral content & $200 \pm 5.50 \mathrm{mg} / \mathrm{gm}$ \\
\hline Total fat content & $200 \pm 3.21 \mathrm{mg} / \mathrm{gm}$ \\
\hline
\end{tabular}

Fig 1: Antimicrobial activity of mustard extracts against $E$. coli isolated from Makerel fish.

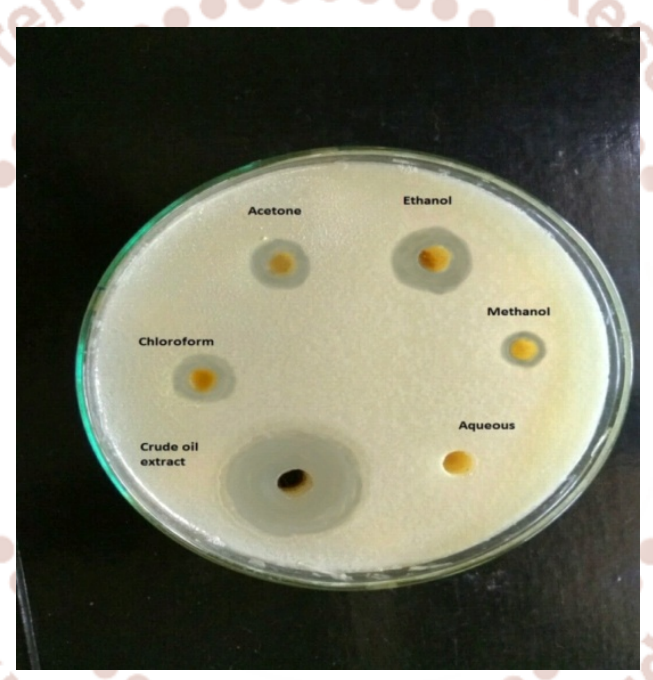

Fig 2. Determination of optimum concentrations of mustard extracts for fish preservation



